\title{
Economic valuation of two environmental services of the Alvarado lagoon system, Veracruz, Mexico
}

\begin{abstract}
The Alvarado lagoon system located in the coastal area of the Gulf of Mexico has great ecological and economic importance and its conservation is paramount from an environmental point of view, given that it has various conservation categories. In this study the economic valuation of two environmental services: provisioning through the mangrove and fishery timber resources, as well as regulation through the sequestration and storage of carbon from the mangrove.The economic value obtained by the mangrove was USD $112,849.88 / \mathrm{ha} /$ day, and for the fishing resources carried out in the lagoon a value of USD $9,610.41$ /day was estimated. As for the Carbon Sequestration and Storage, it was USD $196,089,777$ ha/day. The calculation of the budget price with respect to the economic valuation of the Provisioning was USD 566,652 and for the regulation price it was USD $195,523,125$ with a Total Economic Value for the service of Provision over Regulation of USD 196,089,777ha/day.
\end{abstract}

Keywords: economic valuation, coastal lagoon of Mexico, Alvarado lagoon system
Volume 3 Issue 6 - 2019

\author{
Guadalupe de la Lanza E,' Susana Villanueva \\ $\mathrm{F}^{2}$ \\ Instituto de Biología, UNAM, México \\ ${ }^{2}$ Instituto de Ciencias del Mar y Limnología, UNAM, México
}

Correspondence: Guadalupe de la Lanza E, Instituto de Biología, UNAM, México, Email gdll@unam.mx

Received: November 29, 2019 | Published: December 13, 2019

\section{Introduction}

Ecosystem services are the engine of the environment, they are essential for life; they are becoming an important driving force for the management of natural resources. ${ }^{1-5}$ They have been related to decision making and policies as an innovative strategy for the improved management of land, water and living resources that can promote the conservation of environments. ${ }^{6}$ However, the operation of the concept has often been difficult to achieve, especially to obtain an integrated assessment of the services available in local regions and in the shortage of data. Scientific advances related to the functions of producing ecosystem services, the flow of services and the exchanges between multiple ecosystem services are important increasingly for the practical implementation of the concept in conservation and sustainable development projects. ${ }^{7,8}$

The valuation of ecosystem services (both quantitative and qualitative) and their integration into decision-making policies and practices has been a matter of debate since the concept first emerged in the early $1990 \mathrm{~s}^{9-12}$ The assessment ensures the sustainable use of ecosystems and their elements; protects the natural environments of areas of economic, environmental, archaeological, artistic, cultural and tourist importance, generates a favorable field for scientific research and the study of ecosystems and their balance and protects the hydrological cycle of the basins, as well as others that tend to protect surrounding elements with which the area is ecologically related.

Due to the great ecological and economic importance of the Alvarado lagoon system (ALS) located in the center of the coastal area of the Gulf of Mexico, its conservation is paramount from the environmental point of view, because it has various conservation categories, including the priority hydrological region, among others. Taking into account the environmental characteristics of this system, it is capable of providing different ecosystem services. However, the demand that the human population has on their resources and services, in addition, on the possible environmental, economic and social risks will cause a loss on environmental services, so the objective of this study is to give them a monetary value to two of the environmental services (Supply, Regulation and Carbon Capture) of this system that can be an alternative for conservation and sustainable management of resources.

\section{Study area}

The of Alvarado lagoon system (ALS) is a complex of physicochemical, biological and ecological importance located in the central coastal low zone of the state of Veracruz, in such a way that it constitutes one of the main state centers that capture and supply water. This lagoon system is the main connection of the system with the sea and it finally discharges the runoff from the sub-basins of the Blanco, Camarón and Acula rivers, which are interconnected in the lower part of the basin and the rainy season they originate the formation of a water flood plain that, together with the lagoon system of the area, constitute a large storage vessel. This area has an area of approximately $5240 \mathrm{~km}^{2}$ and represents zone nine percent of the surface of the Papaloapan Basin.

It is located $66 \mathrm{~km}$ from the port of Veracruz, between the coordinates $18^{\circ} 43^{\prime} 51^{\prime \prime}$ and $18^{\circ} 52^{\prime} 40^{\prime \prime} \mathrm{N}$ and $95^{\circ} 42^{\prime} 23^{\prime \prime}$ and $95^{\circ}$ $57^{\prime} 25^{\prime}$ 'W (Figure 1). It is limited to the north by the Gulf of Mexico; to the east both by the Gulf of Mexico and by the complex system of wetlands of the Papaloapan River, the main basin of Alvarado. It has $17 \mathrm{~km}$ of extension along the coastline and $45 \mathrm{~km}$ wide. It is made up of three large lagoons: Alvarado, Buen País and Camaronera, of which the ALS is one of the most important ecosystems in the Gulf of Mexico, due to its significance in obtaining fisheries, but whose habitat is being lost across the coast due to the expansion of urban areas and tourism, as well as activities of intense fishing activity. ${ }^{13}$

It has the largest flood surface in the state of Veracruz and is considered one of the main ecosystems of the flood zone, which 
includes lagoons of various magnitudes and importance, with an area of approximately 267,010 hectares, is considered as the third largest wetland in Mexico and one of the most important for the state of Veracruz, ${ }^{14}$ is also one of the most productive systems in the Gulf of Mexico $^{15}$ and a shelter area for the feeding and reproduction of fish that exist in it. ${ }^{16}$ The must rivers that discharge to the lagoon system of Alvarado are Papaloapan, Acula, Blanco, Limón (Figure 1). Due to the great diversity of activities that are carried out in the Alvarado Lagoon System, such as being considered a cabotage port, of a minor category to navigation and as a docking port for fishing vessels, in addition to the construction and repair of vessels. From the fishing point of view, it is among the most important in Veracruz State, in which the industrial sector predominates, mainly in the conservation and, packaging of meat, fish and seafood. ${ }^{18}$ Fishing activity is the backbone of the economic development of the region, they have had to face havoc with the consequent modernization. For example, the reduction of the lagoon system due to the extension of the agricultural frontier. The dusting of the river system and the contamination of water bodies, derived from the untreated sewage discharges, as well as the capacity of the water bodies for the reproduction of species, have been reduced due to demographic growth.

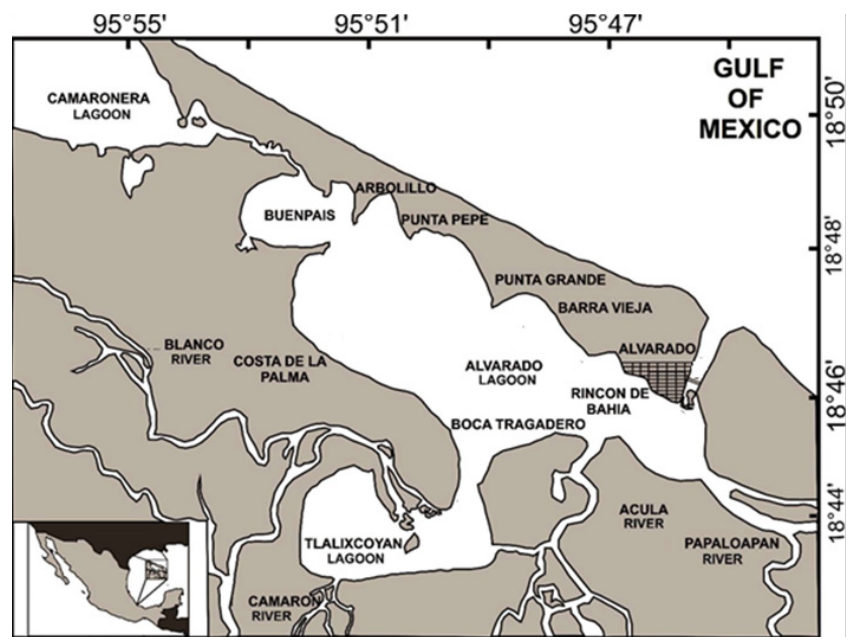

Figure I Study area. Alvarado lagoon system, Veracruz, Mexico (modified $\left.{ }^{17}\right)$.

Waste generated by activities inside and outside the municipal territory are: contamination of bodies of water by industries located outside the municipality but close to it, such as sugar mills, paper mills, textiles, cement factories, cleaning chemicals, crops of cane, soda, beer, alcohol or product of improper handling of solid waste, agrochemicals or from livestock; in addition, the invasion of wetlands due to the expansion of this last activity, the result of unregulated urban growth, which includes modest facilities for tourism to residential developments on dunes and beaches. As a consequence of the above, there are total disturbances or losses of ecosystems: disappearance of natural vegetation, particularly mangrove, by burning practiced by the same inhabitants, to prepare the land for agricultural use, with the consequent reduction of aquatic spaces for reproduction of native species and that, together with the overexploitation of the fishing resource, diminish their potential, for all the above it is convenient to make an economic assessment of the main environmental resources that are affected by the urban and industrial development of the area. The lagoon system is made up of a mangrove community, with small sections of halophyte grasses, among these there are palm trees and some other. During the rainy season, the system is invaded by water lily (Eichornia crassipes), nearby seagrasses such as Ruppia maritima are observed, forming small meadows. The mangrove extension of the Alvarado lagoon complex is 14,897 ha. ${ }^{19}$

\section{Methodology for valuation approaches}

For the calculation of the three environmental services, a methodology known as the economic valuation of the ecosystem services was used, which consists of the allocation of monetary values to the different ecological services. It is used as an instrument to consider ecosystems, including wetlands, as economically productive systems, to later be able to highlight their importance, since providing this analytical basis will allow support in decision-making that provides greater well-being to populations ${ }^{20}$ especially to those who take advantage of resources more directly. The methodology used was the one proposed by de la Lanza et al. ${ }^{21}$ in the article Methodological proposal for economic valuation in coastal systems of Mexico, according to their relative importance (Table 1) for the calculation of the final price, as well as the methodologies used in the Bustamante ${ }^{22}$ in the Practical Guide for the assessment of ecosystem services in Madre de Dios for the identification of the different types of ecosystem services and their respective calculations.

The total economic value of an ecosystem is a concept developed by economists to classify the range of values generated by ecological services. Although there is still no universal agreement regarding terminology, it can be said that the total economic value (TEV) is composed of the active use-value (AUS) and the passive use value (PUV). The active use-value, in turn, is made up of the direct use value (DUV), the indirect use value (IUV) and the option value (OV). For its part, the value of passive use includes the value of legacy (LV) and the value of existence (EV), for two ecosystem services, which are supplies that include fisheries and timber resources obtained from mangroves and carbon sequestration:

$$
T E V=A U V+P U V=(D U V+I U V+O V)+(L V+E V)
$$

AUV is composed of the DUV, the IUV, and the OV. The first is given by the willingness to pay for activities such as recreation, tourism, urbanization, agriculture, fishing, research, among others. These activities may or may not be subject to exchange in the market. Within direct uses of the environment, literature also distinguishes between consumptive uses - which are those that modify the intrinsic nature of the environment; for example, urbanization and intensive agricultural use - and non-consumptive uses - which keep the nature of the environment more or less intact; for example, wildlife observation.

\section{Results}

\section{The total economic value of two environmental services of the Alvarado lagoon complex}

The parameters and variables that define the economic value of the Lagunar Alvarado System are Goods and Services, such as fishing, which includes scale fish and logging from the mangrove. On the other hand, the goods and services produced by the capture and release of $\mathrm{CO}_{2}$. The recognition of the ecosystem services present, as well as the allocation of relative importance in the different ecosystem services, is determined based on the weight they have for the development and functioning of the ecosystem as such. 
Table I Relative importance for two environmental services

\begin{tabular}{|c|c|c|c|c|c|c|c|c|c|c|c|c|c|c|}
\hline System & Prc & isioni & & & & & Reg & latio & & & & & & \\
\hline \multirow{2}{*}{ Alvarado lagoon } & $\mathrm{Al}$ & $\mathrm{A} 2$ & A3 & A4 & A5 & A6 & $\mathrm{RI}$ & R2 & R3 & $\mathrm{R} 4$ & R5 & $\mathrm{R} 6$ & R8 & R9 \\
\hline & 4 & 5 & 0 & 0 & 0 & 0 & 0 & 0 & 0 & 0 & 0 & 0 & 5 & 0 \\
\hline System & \multicolumn{6}{|c|}{ Provisioning } & \multicolumn{8}{|c|}{ Regulation } \\
\hline \multirow{2}{*}{ Alvarado lagoon } & Al & $\mathrm{A} 2$ & $\mathrm{~A} 3$ & $\mathrm{~A} 4$ & A5 & A6 & $\mathrm{RI}$ & R2 & R3 & R4 & R5 & R6 & R8 & R9 \\
\hline & $20 \%$ & $25 \%$ & 0 & 0 & 0 & 0 & 0 & 0 & 0 & 0 & 0 & 0 & $25 \%$ & 0 \\
\hline
\end{tabular}

\section{Provisioning}

Provisioning services are those referred to the number of goods or raw materials that an ecosystem offers, such as wood, water, fisheries, among others. ${ }^{23}$ The prices of the provisioning services were obtained directly through the individual consultation of the resources within an ecosystem in different information portals, as well as articles since they have a market cost, obtained from the present study.

\section{$A \mid=$ Timber resources obtained from the mangrove}

The mangrove species in the SLA from least to greatest flood and salinity are Avicennia germinans, Laguncularia racemosa and Rhizophora mangle. ${ }^{24}$ In 1976 the mangrove area was $211.50 \mathrm{~km}^{2}$ ( 21,150 ha), for 2005 in 29 years it was reduced by $28 \%$, with an area of $152.48 \mathrm{~km}^{2}(15,248 \mathrm{ha})$, in 2010 the mangrove deforestation rate decreased considerably, so It was only $2 \%$, reaching an area of 148.97 $\mathrm{km}^{2}(14,897 \mathrm{ha})$, which represents $17.52 \%$ at the regional level and $1.96 \%$ at the national level. ${ }^{25}$

According to Vázquez-Lule et al., ${ }^{25}$ the use of the different mangrove species at the local level, are for the construction of houses, walls and beams; manufacture of tool ends such as axes and hammers; fuel (fuelwood for consumption and coal for trade); tannins such as net and shrimp dyes; medicinal in the treatment of diabetes, cholesterol and stomach problems; forage for food.

It is important to give an estimated value to this significant resource. The cost of timber resources for one year is obtained from the consultation of the articles by Ajonina et al. ${ }^{26} \&$ Cruz et al. ${ }^{27}$ and which is multiplied by the total area of the mangrove to obtain the total price; based on the aforementioned formula, an economic value provided by the mangrove of USD 2765 /ha $(14,897$ ha which is the mangrove area) was calculated at USD 41,190,205ha/year, and per day it gives a value of USD $112,849.88 /$ ha/day.

\section{A2=Fishery}

The ALS is recognized as a fishermen's site, a place that has been the seat of the development of a regional culture around fishing; due to the habitat of various species of commercial importance, which has given it a role as a generator of food and employment, which has allowed the subsistence of thousands of families living in the environment. Fishery resources cover a wide range of freshwater, euryhaline and marine species, which live temporarily or permanently in the area; the most representative species are the Diplodus vulgaris (mojarra), Mugil curema (robalo), and Lutjanus campechanus (lebrancha) among others. It is the main activity of the Port of Alvarado since it is one of the most important suppliers of fishery products for national and international consumption. In the Papaloapan river basin and consequently in the Alvarado Lagoon System, industries and human settlements cause irreparable damage to the fishery. Among other problems that this system faces are the rainforest of the Papaloapan River and that of the ALS, caused by deforestation in the upper part of the basin, to the extent that there has been a need to dredge the lagoon and the Papaloapan River. This would have negative effects on the populations of the fishing species that reproduce there and that indirectly affect this ecosystem service.

To determine the value of this service, prices per species were consulted in local markets which were added to obtain the price of fishery resources, the sum of which totals $\$ 3,507,798.84$ year. The capture of this resource is made daily at the local level, which contributes a price of USD 3,507,798.84/year, per day gives a value of USD 9,610.41/day. The total economic value of the Supply that includes mangroves and fisheries for this study was USD 566,652.

\section{Regulation}

Regulatory services are those that derive from key ecosystem functions, which help reduce certain local and global impacts, such as climate and water cycle regulation, soil erosion control, and pollination, protection of the coasts against erosion and the impacts of storms, among others. Regulatory services do not have a market price for themselves, so the replacement cost methodology was used, which consists in calculating the expenses necessary to replace a degraded service, or willingness to pay, through objects or systems that if they have a value in the market, which requires the realization of surveys to the inhabitants, in addition, that it adjusts in a good way in view of the fact that the regulatory services do have an equivalent in functions within the market.

\section{$\mathbf{R} 8=$ Carbon sequestration and storage}

One hectare of mangrove forest can hold up to 1000 tons of $\mathrm{CO}_{2}$. Their forests are disappearing at a speed of three to five times faster than global deforestation and as a result, damages are estimated at up to USD 42 billion per year. ${ }^{28}$ Mangroves have a large capacity for $\mathrm{CO}_{2}$ sequestration, so the use of sinks is proposed, such as a $\mathrm{CO}_{2}$ collection plant, whose average price corresponds to the US $\$ 52.5 /$ ton $\mathrm{CO}_{2}$. The carbon sequestration price was obtained from the article by Aguinaco et al. ${ }^{29}$ One hectare of mangroves can sequester up to 1000 tons of $\mathrm{CO}_{2}$. The following results are obtained 1000-ton $\mathrm{CO}_{2} /$ ha $(14,897 \mathrm{ha})=14,897,000$ ton $\mathrm{CO}_{2} \cdot 14,897,000$-ton $\mathrm{CO}_{2}(52.5 \mathrm{US} \$ /$ ton $\mathrm{CO}_{2}$ ) gives a value of $782,092,500 \mathrm{USD} / \mathrm{ha} /$ day.

\section{Total budget price calculation}

From the proposal modified by de la Lanza et al., ${ }^{21}$ the following formula was used:

$$
T i E V=(A 1 V)+(A 2 V)+(A 3 V)+\ldots(A n V)
$$


Where:

TiEV=Total Economic Value of the environmental component $i$

RISn=Relative Importance of the Environmental Service $n$

$\mathrm{AnV}=$ Economic value of the environmental service $\mathrm{n}$

TEV provisioning $=112,849.88$

$(0.25)=564,249.40+2,402.60=$ USD 566,652

TEV regulation $=782,092,500(0.25)=195,523,125$ USD

$\mathrm{TEV}=566,652+195,523,125=\mathrm{USD} 196,089,777$ ha $/$ day

$\mathrm{TEV}=\mathrm{Total}$ Economic Value for the provisioning service that includes the timber resource of mangroves and fisheries and the Regulation that is considered carbon sequestration, with a value of USD 196,089,777ha/day.

\section{Discussion}

From the results obtained on the Provision corresponding to the uses that are given to the mangrove wood, it can be said that the mangrove forests are found along the oceanic coasts in the tropics and are compatible with numerous ecosystem services, including fishery production. However, the extension of the area of mangrove forests has decreased by $30-50 \%$ over the past half-century as a result of coastal development, the expansion of aquaculture and overexploitation. ${ }^{30,31}$ Carbon emissions resulting from the loss of mangroves are uncertain, due in part to the lack of large-scale data on the amount of carbon stored in these ecosystems, particularly underground..$^{32}$ Due to their ability to sequester and store carbon, mangroves are increasingly at the center of climate mitigation actions. Carbon sequestration and the measurement of greenhouse gases have emerged as services of interest, perhaps due to increasing emphasis on the "blue carbon" of coastal and marine ecosystems. ${ }^{33}$

Natural and environmental resources can provide more than one good or service at a time. As an example of this situation, we could mention the case of a mangrove forest, which in addition to providing wood as a market good, can fulfill the function of water regulator, carbon dioxide assimilator or as a habitat for wild species. ${ }^{34}$ Similarly, they degrade organic matter and even store some waste used in agriculture. Without this meaning that mangroves are immune to pollution, it has been estimated that one hectare of mangrove is equivalent to the annual operating cost of a sewage treatment plant, estimated at around $\$ 150,000$ USD. ${ }^{35}$

According to the previous information, the estimated ecosystem service values of the mangrove timber resources were USD 112,849.88/ ha/day for this study, which compared to that carried out in Costa Rica for 2005 was USD 266,851,917 which is a one hundred times smaller order, due to the extension that covers the mangroves of Costa Rica. ${ }^{36}$ As for fisheries, production tends to decrease, this is a complex problem with different aspects, social related to your organization, mainly under the category of cooperatives, techniques: probably caused by the lack of training or ignorance of the arts of the fishing, economic; due to the absence of financing or markets, ecological and / or environmental; basically due to the presence of different types of pollution, as well as the deforestation of the mangrove. In addition to the problems of the regulatory nature of fishing for a certain species, aimed at avoiding over exploitation.

The ALS is recognized as a fishermen's site, a place that has been the seat of the development of a regional culture around fishing; because it is the habitat of various species of importance to the system, which has given it a role as a generator of food and employment, which has allowed the subsistence of thousands of families living in the environment. This leads to an estimated cost for this study that is 9,610.41USD/day, compared to the study conducted by YañezArancibia $^{37}$ for the Bay of Campeche, calculated a value of USD 900, this value is an order of magnitude less to the one reported for this study, which is USD 9,610.41/day, this difference may be due to the fact that in the first case a regulated fishery scheme is assumed in an area where the behavior is open-access fishing or distribution among coastal fishermen and offshore. ${ }^{38}$ For this reason, it is considered that the determination of the value for fisheries protection should be done on a case-by-case basis, considering not only the biological aspects but also those of social and industrial organization of fishermen and forest holdings. ${ }^{39}$

Regarding the regulation service that corresponds to carbon sequestration and storage, it can be said that the capacity of the mangrove forest to store such large amounts of carbon can be attributed, in part, to the deep soils rich in organic matter in which it generates. Mangrove sediment carbon reserves were on average five times larger than those observed in temperate, boreal and tropical terrestrial forests, per unit area. The complex mangrove forest root systems, which anchor the plants in underwater sediments, allow, through the incoming tidal waters, that the organic and inorganic material diffuses into the surface of the sediment. Low oxygen conditions decrease decomposition rates, which results in much of the $\mathrm{CO}_{2}$ accumulating in the sediment. In fact, mangroves have more carbon than in their soil than most tropical forests in all their biomass and soil combined. ${ }^{40}$ Donato et al. ${ }^{41}$ estimated that mangroves contain, on average, 1,023tons of carbon per hectare, which makes them one of the richest ecosystems in this element. Because they are so rich in carbon, the destruction or alteration of wetlands could release huge amounts of $\mathrm{CO}_{2}$ into the atmosphere. Donato et al. ${ }^{41}$ they calculated that the destruction of mangroves worldwide could release 73 to 440 million tons of $\mathrm{CO}_{2}$ every year $(0.02-0.12 \mathrm{PgC})$. Similarly, Aguiaco ${ }^{29}$ mentions that the oceans represent by far a sink with great potential, which contains approximately $40,000 \mathrm{GtC}$ (trillion metric tons of carbon), compared to only $750 \mathrm{GtC}$ in the atmosphere and 2,200GtC in the Earth Biosphere.

According to Asqueta $^{42}$ mention that economically the Environmental Goods and Services generated by the mangrove ecosystem, will allow to highlight their potential of biological resources, making possible the management of biotic indicators in the region, as well as highlighting the role of the mangrove forest as an important resource in the offer of greenhouse reduction services - $\mathrm{CO}_{2}$ fixation and $\mathrm{O}_{2}$ release. This assessment can become a useful instrument for ecosystem management.

Mangroves are excellent evotranspirators since they significantly supply moisture to the atmosphere and in doing so they become a source of natural cooling for nearby communities. ${ }^{42}$ They act as natural sinks of $\mathrm{CO}_{2}$ and a source of organic and inorganic matter, and constitute important links in the food chain because of their function as energy transfers to secondary systems. ${ }^{42}$ Similarly, Aguinaco ${ }^{29}$ asserts that, in the absence of international agreements, it is not clear whether the various forms of $\mathrm{CO}_{2}$ capture and storage will be treated as emission reductions or as elimination of atmospheric emissions. The technique of $\mathrm{CO}_{2}$ capture and storage differs clearly and in many aspects of $\mathrm{CO}_{2}$ sequestration in biological carbon sinks (forests, soil, etc.), while the different forms of capture and storage differ from each 
other. Donato et al. ${ }^{41}$ mention that mangroves are important carbon sinks $\left(1,023 \pm 88-1,520 \pm 163 \mathrm{Mg}\right.$ of $\left.\mathrm{C} \mathrm{ha}^{-1}\right)$ and have high efficiency in capturing atmospheric $\mathrm{CO}_{2}$, sequestering up to 25.5 million tons of carbon per year.

Adame $^{43}$ presents an example of this type of study, where the sediment that was recently exposed in the Tajamar lagoon in Quintana Roo, Mexico could have been buried for hundreds of years and due to conditions such as lack of oxygen. It decomposes when the vegetation is removed and the sediment is exposed to oxygen from the environment, decomposition begins and the resulting $\mathrm{CO}_{2}$ begins to be released into the atmosphere. If Tajamar is not restored, the carbon that would be released would be approximately 133,000 tons of $\mathrm{CO}_{2}$, valued at 1.4 million euros in the European Union Carbon Emission Trading System. The mangroves of Quinta Roo are small, measuring no more than $20 \mathrm{~cm}$, but their roots have sediment of 50 $60 \mathrm{~cm}$ of carbon. The amount of carbon that these small mangroves have is equal to that of rainforest in Chiapas Mexico with giant trees. ${ }^{44}$ Adame $^{43}$ for the Tajamar lagoon in Quintana Roo calculated value of $1,540,844 \mathrm{USD}$, lower value compared to that of the Alvarado lagoon up to $50 \%$ which is $782,092,500 \mathrm{USD} / \mathrm{ha}$ /day.

Another example is the carbon sequestration rate of the mangroves of the La Encrucijada Biosphere Reserve Mexico, as a whole, it is almost 40,000 tons of carbon per year, which is equivalent to the annual emissions of 10,400 Mexicans. In the case of the Sian Kaan Biosphere Reserve, carbon reserves are between 43 to 58 million tons of carbon, equivalent to 186 million tons of $\mathrm{CO}_{2}$, which in 2009 accounted for half (40-46\%) of all carbon emissions in the country (400million tons of $\mathrm{CO}_{2}$ ). This implies that if the Sian Kaan wetlands are destroyed by a combination of land-use change or by the effects of climate change, the wetlands in this area would release about half of the annual $\mathrm{CO}_{2}$ emissions of the entire country ${ }^{43} \mathrm{~A}$ recent study in the mangrove soils of the Galapagos Islands, Tanner et al. ${ }^{44}$ reported that the Galapagos mangrove soils store about 211 tons/ha of carbon, representing a total of more than 778,000 tons of carbon. The estimated cost of carbon stored in the Galapagos mangroves is worth more than USD 27,852ha. The TEV obtained from TEV=Total Economic Value was equal to USD 196,089,777ha/day considering two services, which is the result of a series of data obtained from the market, the values are subjective, because it changes in the short, medium and/or long term. This is because the obtaining of information was scarce due to its low availability, which can vary the real price, so the amount obtained is an approximate, coupled with the fact that the purely economic valuation has as an indirect consequence that an ecosystem determined can be undervalued or overvalued. ${ }^{22}$

Anthropogenic pressures are reducing the global distribution of mangroves and extensive areas have been destroyed directly or as a result of various activities. The mangrove forest of the ALS is currently in a frank process of degradation due to its alteration to grasslands, which are frequently used for livestock, with the respective consequences of degradation of this ecosystem. ${ }^{19}$ This process of degradation of mangroves due to indiscriminate logging causes a lower density every year. The main reason for the deforestation of hundreds of hectares has been the indiscriminate development of agriculture, followed by livestock activity and urban growth, which has caused, among other things, the modification of hydrology due to deviations of river channels with agricultural purposes and the substitution of mangrove areas, for aquaculture or tourism infrastructure, among others..$^{45}$ Given that the ALS not only represents a good part of the coastal zone of the state of Veracruz but the decrease has also been $17 \%$ of mangroves between 1976 and $2015 .{ }^{46}$ For the present study, the price obtained for timber resources from mangroves was USD $112,849.88 \mathrm{USD} / \mathrm{ha} /$ day.

de la Lanza et $a 1 .{ }^{46}$ reports that the absence of policies and instruments to assess the loss or transformation of goods and services offered by ecosystems in Mexico and particularly in the coastal zone, has generated social conflict situations when events caused by activities have occurred human beings that have disturbed natural environments and where such absence has limited the assignment of responsibilities and therefore, the mechanisms of recovery or compensation of the damage. In the same way, the evaluation of the damages generated by the presence of extreme climatic events and the consequences that derive from them on the coastal environments, have not been able to calculate in their entirety as there are no elements that allow knowing the effects of the accident beyond the obvious and superficial, without considering its derivations on the mechanisms and processes that intervene to provide goods and services to the human population.

The main causes of the loss of mangroves are due, in summary, to the application of productive economic policies oriented towards obtaining short-term profits. These causes include irrational logging, modification of hydrology due to deviations of river beds for agricultural purposes, the substitution of mangrove areas for aquaculture works or tourism infrastructure, among others. The lack of management plans for these types of vegetation and the limited planning and ordering of productive activities and the lack of knowledge or difficulty in determining the ecological and economic value of the goods, attributes, and services provided by these environments are also important causes of their disappearance. ${ }^{14}$

\section{Conclusion}

The economic valuation of the Provisioning Services associated with the mangrove, fishery and Regulatory timber resources related to the capture and elimination of $\mathrm{CO}_{2}$ was calculated for this tropical lagoon system. The calculated values compared to other tropical regions of the southern Gulf of Mexico and the Mexican Caribbean, as well as coastal areas of Costa Rica and the Galapagos Islands are heterogeneous, due to the differences that exist between each of these coastal areas, in terms of extension, location, preservation, as well as the impact they have had on differences in land use, population growth, exploitation of their resources, and the lack of a responsible policy. The of Alvarado lagoon system represents a first important approximation within the economic valuation, since the ecosystem shows a constant deterioration, not only due to overfishing, immoderated felling of mangrove, land use change, damage due to pollution and the excessive use of its resources.

\section{Acknowledgments}

None.

\section{Conflict of interest}

The authors declare that there is no conflict of interest.

\section{Funding}

None.

\section{References}

1. Costanza R, d'Arge R, Rudolf C, et al. Special Section: Forum on Valuation of Ecosystem Service. The value of ecosystem services: putting the issues in perspective. Ecological Economics. 1998;25:67-72. 
2. Millenium Ecosystems Assessment. Ecosystems and Human WellBeing: Wetlands and water. 2005.

3. TEEB. In: Kumar P, Editors. The Economics of Ecosystems and Biodiversity: Ecological and Economic Foundations. Earthscan, London and Washington DC. 2010.

4. Díaz S, Demissew S, Carabias J. et al. The IPBES Conceptual Framework-connecting nature and people. Curr Opin Environ Sustain. $2015 ; 14: 1-16$

5. FAO. Proteger los servicios ecosistémicos y la biodiversidad: la misión y las soluciones de la FAO. FAO. 2019.

6. Haines-Young R, Potschin M. The link between biodiversity, ecosystem services and human well-being. In: Rafaelli D, Frid C, Editors. Ecosystem Ecology; A New Synthesis. Cambridge University Press, Cambridge. 2010;110-139.

7. Daily GC, Polasky S, Goldstein J, et al. Ecosystem services in decision making: time to deliver. Front Ecol Environ. 2009;7(1):21-28.

8. Ash N, Blanco H, Garcia K, et al. Ecosystems and Human Well-Being. A Manual for Assessment Practitioners. Island Press, Washington, DC. 2010

9. Costanza R, d'Arge R, de Groot R, et al. The value of the world's ecosystem services and natural capital. Nature 1997;387:253-260.

10. Daily GC. Nature's Services: Societal Dependence on Natural Ecosystems. Washington, DC. Covelo, California. 1997.

11. De Groot R, Fisher B, Christie M. Integrating the ecological and economic dimensions in biodiversity and ecosystem service valuation. In: Kumar P, Editors. The Economics of Ecosystems and Biodiversity: Ecological and Economic Foundations. TEEB Foundations. 2010.

12. Guerry AD, Polasky S, Lubchenko J. et al. Natural capital and ecosystem services informing decisions: from promise to practice. Proc Natl Acad Sci USA. 2015;112(24):7348-7355.

13. Cruz-Escalona VH, Arreguín-Sánchez F, Zetina-Rejón M. Analysis of the ecosystem structure of Laguna Alvarado, western Gulf of Mexico, by means of a mass balance model. Estuarine Coastal and Shelf Science. 2007;72(1-2):155-167.

14. Moreno Casasola P, Rojas Galaviz JL, Zarate Lomelí D, et al. Diagnosis of the mangroves of Veracruz: distribution, link with fishery resources and their problems. Woods and forests. Institute of Ecology, AC, Xalapa, See. 2002;8(1):61-88.

15. Guentzel LG, Portilla E, Ortega AA, et al. The Alvarado lagoonEnvironment, Impact and Conservation. Chapter 14. In: Lagoons: Biology. Management and Environmental Impact. 2011;397-415.

16. Portilla-Ochoa E. Establishment of Environmental Management Units in the Wetland of Alvarado, Veracruz Mexico: Basis for Ecological and Social Management. Biannual North American Wetlands Conservation Council (NAWCC) academic report. Conservation Biology Area. Biological Research Institute. Veracruz University. 2003.

17. Ponce-Vélez G, de la Lanza Espino G. Organophosphate Pesticides in Coastal Lagoon of the Gulf of Mexico. Journal of Environmental Protection, 2019;10(2).

18. González-Martínez JR. General socioeconomic aspects. In: National Fisheries Institute and Veracruzana University (coord.). Fishing in Veracruz and its development prospects. Government Editor of the State of Veracruz. Xalapa, Veracruz. Mexico. 2002;259-276.

19. Rodríguez-Zuñiga MT. Mangroves of the lagoon system of Alvarado Mexico influence of some physical, biological and anthropogenic processes in their structure and distribution. Master's Thesis. Science Faculty. UNAM. 2002. 104 p.
20. Arana MV. Analysis and assessment of wetland ecosystem services associated with the León River (Uraba Anrioqueño-Colombia. Its relationship with the underground water system and with human wellbeing. Master's degree in environmental assessment of water systems. $2015 ; 1(4) 1-92$.

21. De la Lanza-Espino G, Ruiz A, Fuentes P, et al. Methodological Proposal for economic valuation in coastal systems of Mexico. In: Botello AV, Villanueva S, Editors. Mexican Coasts, Pollution, Environmental Impact, Vulnerability and Climate Change. 2019.

22. Bustamente MP, Ochoa E. Practical guide for the valuation of ecosystem services in Madre de Dios. WWF Perú. 2014;11:36-41.

23. http://blog.creaf.cat/es/conocimiento/que-son-los-serviciosecosistemicos/

24. Reséndez MA. Study of the fish from the Laguna de Alvarado, Veracruz, Mexico. Soc Mex Hist Nat Magazine. 1973;31:183-281.

25. Vázquez- Lule AD, Rodríguez-Zúñiga MT, Ramírez-García P. Characterization of the mangrove site Sistema Lagunar de Alvarado Veracruz, in the National Commission for the Knowledge and Use of Biodiversity (CONABIO). Mangrove sites with biological relevance and with ecological rehabilitation needs. CONABIO. 2009.

26. Ajonina GN, Agardy T, Lau W, et al. Mangrove Conditions as Indicator for Potential Payment for Ecosystem Services in Some Estuaries of Western Region of Ghana, West Africa. The Land/Ocean Interactions in the Coastal Zone of West and Central Africa. 2014;159:151-166.

27. Cruz SM, Marroquín N, Álvarez LE, et al. Evaluation of Mangrove (Rhizophora mangle L.) products as coloring, antimicrobial and antioxidant agents. International Journal of Phytocosmetics and Natural Ingredients. 2015;2(1):12.

28. https://www.elcomercio.com/tendencia/manglares-co2cambioclimatico-ecuador-deforestacion.html

29. Aguinaco VJ. Capture and storage of carbon dioxide. Engineering Academy. 2008;23.

30. Polidoro BA, Carpenter KE, Collins L, et al. The loss of species: mangrove extinction risk and geographic areas of global concern. PLoS One. 20105:e10095

31. United Nations Organization for Food and Agriculture. FAO. 2007.

32. Bouillon S, Borges AV, Castañeda-Moya E, et al. Mangrove Production and Carbon Sinks: A Revision of Global Budget Estimates. Global Biogeochemical Cycles. 2008;22(2):GB2013.

33. Tibor Vegh. Mangrove Ecosystem Services Valuation:State of the Literature. Nicholas Institute for Environmental Policy Solutions. 2014;1-15.

34. Costanza R, de Groot R, Sutton P, et al. Changes in the global value of ecosystem services. Global Environmental Change. 2014;26(1):152158.

35. http://peninsulatres.com/pais-1/otros/el-valor-de-los-manglares-65

36. http://cicostarica.org/es/value-economico-de-los-manglares

37. Yañez-Arancibia A, Seijo JC, Lara-Dominguez AL, et al. Economic Valuation of ecosystems: the case of mangroves. Ecology, fisheries and oceanography program of the Gulf of Mexico (EPOMEX), Campeche, Mexico. 1995.

38. Gammage S. Estimating the Returns to Mangrove Conversion: Sustainable Management or Short Term Gain. Londres, International Institute for Environment and Development (IIED), London Environmental Economic Programs (LEEP) Discussion Paper. 1997;97102. 
39. Sanjurjo-Rivera E, Welsh CS. A description of the value of the environmental goods and services provided by the mangroves Gaceta Ecológica. Ministry of Environment and Natural Resources. Federal District, Mexico. 2005;55-68.

40. World Rainforest Movement. The carbon market takes over mangroves. World Rainforest Movement. 2011.

41. Donato DC, Kauffman JB, Murdiyarso D, et al. Mangroves among the most carbon-rich forests in the tropics. Nature Geoscience. 2011;4(5):293-297.

42. Azqueta D. Comparative Advantages and Exploitation of Natural Resources. ECLAC Magazine. 1999;68:115-136.

43. Vargas-Parada L. Destroying mangroves releases greenhouse gases. Ecology. 2016.
44. Tanner MK, Moity N, Costa MT, et al. Mangroves in the Galapagos: Ecosystem services and their valuation. Ecol Econ. 2019;160:12-24.

45. Portilla-Ochoa E. Establishment of Environmental Management Units in the Wetland of Alvarado, Veracruz, Mexico: Basis for Ecological and Social Management. Biannual North American Wetlands Conservation Council (NAWCC) academic report. Conservation Biology Area. Biological Research Institute. Veracruz University. 2003.

46. De la Lanza-Espino Ruiz AG, Fuentes P. et al. Methodological proposal for economic valuation in coastal systems of Mexico. Environmental research Science and public policy. 2013;5:1 